\title{
Cutaneous finger and tongue metastases in renal cell carcinoma
}

\author{
Calvin Abro, ${ }^{01}$ Ramy Sedhom, ${ }^{2}$ Abha Soni, ${ }^{3}$ Mark Markowski ${ }^{2}$
}

'Internal Medicine, Michigan State University, East Lansing, Michigan, USA

${ }^{2}$ Oncology, Johns Hopkins Hospital, Baltimore, Maryland, USA

${ }^{3}$ Pathology, Johns Hopkins Hospital, Baltimore, Maryland, USA

\section{Correspondence to Dr Calvin Abro,} ABROCALV@MSU.EDU

Accepted 8 June 2019

\section{DESCRIPTION}

A 54-year-old man with metastatic, undetermined subtype, renal cell carcinoma (mRCC), chronic obstructive pulmonary disease, hypertension and diabetes mellitus presented with dyspnoea and increased oxygen requirement of 5 days duration. At baseline, he required $2 \mathrm{~L}$ of oxygen due to pleural carcinomatosis and lymphangitic spread of disease. On presentation, he was tachycardic at 121 beats per minute, hypertensive and afebrile, and saturating at $95 \%$ on $3 \mathrm{~L} / \mathrm{min}$ of oxygen. Examination was notable for new hyperaemic pustules on his fingertips, resembling a pyogenic granuloma (figure 1), and an indurated, papillary growth on his tongue (figure 2). A complete blood count and comprehensive metabolic profile were within normal limits. A CT of the chest showed a new moderate right-sided pleural effusion. The differential diagnosis included an immune-related

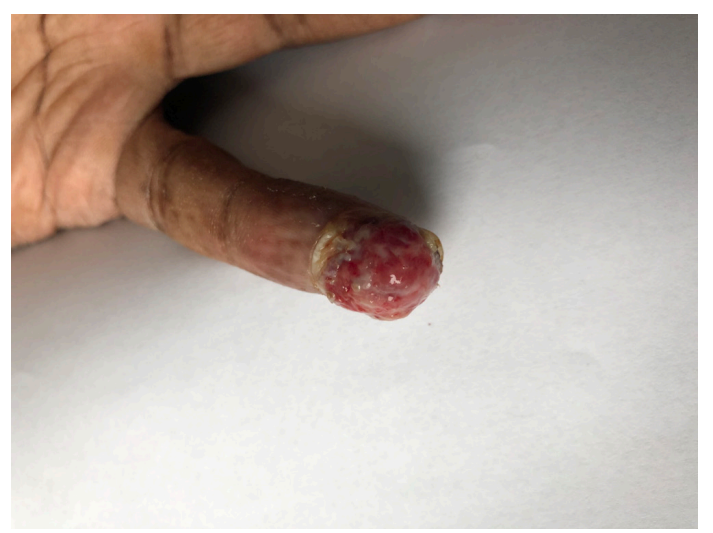

Figure 1 Hyperaemic pustule on the finger resembling a pyogenic granuloma.

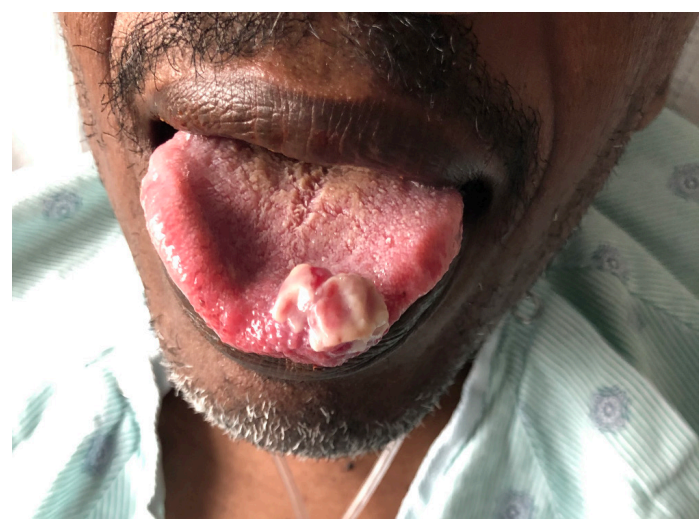

Figure 2 Tongue lesion which developed while on nivolumab.

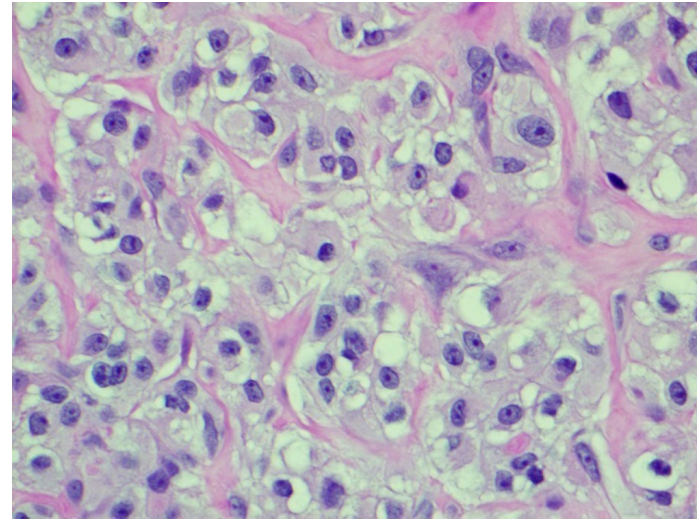

Figure 3 Shave biopsy of the finger showing histology consistent with metastatic renal cell carcinoma.

adverse event from prior checkpoint inhibitor therapy or related to progression of disease. Dermatology was consulted, which performed a shave biopsy of his finger lesion. Pathology was morphologically consistent with mRCC (figure 3). Ten months prior to this admission, the patient was diagnosed with RCC with metastases

\section{Patient's perspective}

I am frustrated that my cancer is not slowing down with the chemotherapy. My doctor is going to try some other chemotherapy regimen to see if that works. The bumps on my fingers and tongue are inconvenient, but I am just happy that I can still play with my son at home. I hope that my cancer can be cured one day.

\section{Learning points}

- The pattern of metastatic spread of renal cell carcinoma is variable and can include the skin and the tongue.

- Cutaneous lesions may resemble common dermatological lesions such as a pyogenic granuloma.

- Biopsy is warranted to help guide therapy and confirm the diagnosis.

- Single cutaneous lesions may be treated with resection or radiotherapy.

- Multiple metastatic cutaneous lesions require therapy with an angiogenesis and multiple kinase inhibitor. 
to the lung and bones. The patient had a short response to cabozantinib and progressed through nivolumab as secondline therapy. These skin and tongue lesions developed while on nivolumab. He is currently undergoing therapy with everolimus and lenvatinib, with regression of both skin and tongue lesions noted after 3 weeks of therapy.

Cutaneous metastasis of renal cell carcinoma is rare, occurring in approximately $1 \%-3 \%$ of cases. ${ }^{1}$ Koga and colleagues ${ }^{2}$ observed that the most common sites for skin metastasis were the trunk (40\%), scalp (25\%) and face (9\%). The prevalence of tongue metastases is estimated to be $0.17 \%$. $^{3}$ Similarly, metastasis to the distal extremities is also rare and represents $<0.2 \%$ of all metastatic lesions. ${ }^{4}$ Although single skin lesions may be treated with either surgical resection or radiotherapy in some cases, metastatic lesions typically require systemic therapy with an angiogenesis/multiple kinase inhibitor. ${ }^{5}$ Our patient had multiple lesions on his fingers and on his tongue, which would likely have caused disfigurement if treated with resection. Instead he was treated with the angiogenesis inhibitor everolimus and multiple kinase inhibitor lenvatinib with promising results. The case is an important reminder to consider the embolic phenomena of mRCC.
Contributors CA contributed to the first draft of the article, as well as obtaining images and consent from the patient. RS contributed to further clinical data gathering pertaining to the case as well as editing the manuscript. MM contributed to editing the manuscript as well as providing key details regarding the patient described in the case. AS provided the pathology images.

Funding The authors have not declared a specific grant for this research from any funding agency in the public, commercial or not-for-profit sectors.

Competing interests None declared.

Patient consent for publication Obtained.

Provenance and peer review Not commissioned; externally peer reviewed.

\section{REFERENCES}

1 Badiu CD, Aungurenci A, Manea CA, et al. Axillary skin metastasis of renal cell carcinoma-Case report. Int J Surg Case Rep 2017;34:74-6.

2 Koga S, Tsuda S, Nishikido M, et al. Renal cell carcinoma metastatic to the skin. Anticancer Res 2000;20:1939-40.

3 Altuntaş 0 , Petekkaya I, Süslü N, et al. Renal cell carcinoma metastatic to the tongue: a case report and review of the literature. J Oral Maxillofac Surg 2015;73:1227-30.

4 Hernández-Cortés P, Caba-Molina M, Gómez-Sánchez R, et al. Renal clear cell carcinoma acrometastasis. an unusual terminal condition. J Hand Microsurg 2015;7:149-51.

5 Arrabal-Polo MA, Arias-Santiago SA, Aneiros-Fernandez J, et al. Cutaneous metastases in renal cell carcinoma: a case report. Cases J 2009;2:7948.

6 Airoldi M, Succo G, Valente G, et al. Head and neck metastases of renal cancer after nephrectomy: a report of 2 cases. Tumori 1995;81:213-4.

Copyright 2019 BMJ Publishing Group. All rights reserved. For permission to reuse any of this content visit

https://www.bmj.com/company/products-services/rights-and-licensing/permissions/

BMJ Case Report Fellows may re-use this article for personal use and teaching without any further permission.

Become a Fellow of BMJ Case Reports today and you can:

- Submit as many cases as you like

- Enjoy fast sympathetic peer review and rapid publication of accepted articles

- Access all the published articles

Re-use any of the published material for personal use and teaching without further permission

Customer Service

If you have any further queries about your subscription, please contact our customer services team on +44 (0) 2071111105 or via email at support@bmj.com.

Visit casereports.bmj.com for more articles like this and to become a Fellow 